\title{
So you want to do biocodicology? A field guide to the biological analysis of parchment
}

\author{
Sarah Fiddyment ${ }^{1 *} \mathbb{D}$, Matthew D. Teasdale ${ }^{1 *}$, Jiří Vnouček ${ }^{1,2,3}$, Élodie Lévêque ${ }^{4,5}$, Annelise Binois ${ }^{6}$
}

and Matthew J. Collins ${ }^{7,8}$

\begin{abstract}
Biocodicology, the study of the biological information stored in manuscripts, offers the possibility of interrogating manuscripts in novel ways. Exploring the biological data associated to parchment documents will add a deeper level of understanding and interpretation to these invaluable objects, revealing information about book production, livestock economies, handling, conservation and the historic use of the object. As biotechnological methods continue to improve we hope that biocodicology will become a highly relevant discipline in manuscript studies, contributing an additional perspective to the current scholarship. We hope that this review will act as a catalyst enabling further interactions between the heritage science community, manuscript scholars, curators and conservators.
\end{abstract}

Keywords: Manuscripts, Proteomics, Genetics, Codicology, Biocodicology, Microbiome

\section{Introduction}

Parchment, a writing support whose origins are believed to be in ancient Pergamon, represents an irreplaceable source of historical, artistic and societal information [1]. Over the centuries parchment has been the foundation for a multitude of media from illuminated Gospels to the utilitarian documents used in everyday life.

Aside from the text, the physical parchment object holds vast quantities of biological information thatalthough in many cases is invisible to the naked eyecan be used to provide a deeper level of understanding about book production, livestock economies, handling, conservation and the historic use of the object [2-4]. This emerging field that we have termed "biocodicology" looks to unlock these biological signals to allow a greater understanding of the manuscript as a physical object.

Codicology is the study of the physical structure of the book, which promotes a better understanding of its production and subsequent history [5]. It is often referred to as "the archaeology of the book", concerning itself with the materials (parchment, sometimes referred to as membrane

*Correspondence: sarah.fiddyment@palaeome.org;

matthew.teasdale@palaeome.org

1 BioArCh, Department of Archaeology, University of York, York YO10 5DD, UK

Full list of author information is available at the end of the article or vellum, paper, pigments, inks and so on), and techniques used to make books, including their binding [6].

Biocodicology, the study of the biological information stored in manuscripts, looks to expand the field of codicology to include the biomolecular techniques of proteomics [3] and genomics $[4,7]$ to further develop our understanding of how manuscripts were produced and used through history and how this can help shape and inform our views of the past. This review is intended to provide a primer to this emerging field highlighting the challenges and opportunities in conducting these novel analyses with heritage objects. While our review focuses on the application of biocodicology to parchment based objects, for example highlighting the animal origins of the documents, many of the techniques may also be applied to paper books when targeting, for example, microbiome data or glues and surface treatments. We hope that this review will be used as a guide for conservators and curators on the possible applications of biocodicology to their collections, by illuminating the potential opportunities it offers.

\section{The evolution of codicological analysis-from manuscript to molecule}

Original biological analysis

That parchment documents house biological data is not a new observation; follicle patterns of the animals used 
to produce parchment and leather have likely served as a proxy for the identification of breed and species since the beginning of parchment making itself $[2,8]$. This method relies heavily on the subjective experience and training of the user, which can lead to errors (for example, many catalogued sheepskin parchments are classified as vellum) as natural biological variation can often lead to misidentification. In addition, follicle patterns are not always visible and can therefore not be used as an objective or routine method of species identification. Michael Ryder, a pioneer of the follicle pattern analysis of parchment, was able to determine different wool qualities which he believed could be linked to particular breed types. However, the analysis he performed required thin section microscopy of parchment fragments, which necessitated destructive sampling and therefore greatly limited the number and type of samples that could be analysed [9].

Looking at the biomolecular data contained within books is again not a new idea $[10,11]$, but early attempts to investigate the biomolecular composition of parchment proved to be harder than initially imagined. Due to the nature of the technologies at the time, destructive sampling of the documents was necessary to obtain sufficient amounts of starting material to analyse. This intrinsically limited the kind of analyses that could be adopted as routine or that were even feasible, with only a very small number of documents being chosen as proof of concept studies rather than a large scale analysis. Initially the focus lay on the retrieval of genetic material, with pioneering studies demonstrating the difficulties inherent to the methodologies of the time (contamination and a lack of sensitivity), but also highlighting the possibilities that genetic analyses could provide [1,11-15]. Early proteomic analysis using mass spectrometry appeared to be more successful, the pioneering study of Toniolo et al. [16] used a high profile document, believed to be Marco Polo's Bible, to demonstrate the importance of their technique and achieve species identification. Limitations of their extraction technique, database and technical sensitivity meant however that a few other animals couldn't be categorically excluded, and, as with genetic analysis, their protocol required destructive sampling $(5 \mathrm{mg}$ of parchment) rendering it an intriguing but not universally adoptable analysis.

In addition to the parchment itself, there have also been studies investigating the biological microenvironment of manuscripts. There has been a long-standing interest from the conservation community in identifying potentially damaging microorganisms that inhabit these documents in order to assess the risk they pose [17]. Traditional methods involving swabbing, bacterial culture and basic DNA sequencing provide some information but can be limited in that they preferentially only select the most abundant species leading to a somewhat biased interpretation. However, these methods are now accepted by the conservation community and have been successful within their limitations [17-20].

\section{The omics revolution}

During the last decade, we have seen both a genomic and proteomic revolution, offering the technological advances necessary to more fully unlock the biomolecular data held within parchment documents and historical artefacts in general [21]. The fundamental change of methodology within 'omics' is that it takes a so-called 'shotgun' approach, whereby instead of targeting a specific set of molecules you instead extract and identify all the biomolecules present, providing a 'biomolecular snapshot' of the environment. This approach has the advantage of detecting possibly surprising elements, that would not be identified in a more targeted approach, leading to unexpected discoveries. It also gives a more representative assessment of the environment analysed and can allow for relative quantification of identified elements.

First, we will review the terminology involved. Three types of biomolecular analyses can be undertaken: genetics (DNA), proteomics (proteins) and the microbiome (microbial genetics), which all have different information to contribute. By playing to each methods strengths, we can reveal a more complete biological picture of the document to aid in its study and conservation.

\section{What is genetic analysis?}

Deoxyribonucleic acid (DNA) makes up one of the four main categories of biomolecules that also include carbohydrates, lipids (fats) and proteins, and carries an organism's genetic code. Famously found to be a helical structure, DNA holds the blueprint of who we are [22]. By extracting and sequencing DNA we can detect the species and sex of the parchment animal and by analysing the small differences in the genetic code we can determine possible breed variation (dependant on geography) and relatedness to other individuals $[1,4,7,11-$ 15, 23-25]. However, we must be aware that the DNA we extract from parchment is of a variable quality and abundance compared to DNA sampled from living individuals $[4,26]$. This will inevitably affect the resolution of the analysis and might compromise the level of detail we would like to achieve. This inherent complication has to be kept in mind when deciding to undertake a (possibly lengthy and costly) genetic analysis of historical documents. A counterpoint to this is that in the last decade technological advances have exponentially increased the amount and quality of genetic data that can be recovered from degraded specimens, by replacing traditional 
DNA sequencing methods with so-called next generation sequencing (NGS). These new high throughput DNA sequencing techniques (HTS) are ideally suited to sequence damaged DNA from historical and archaeological sources (reviewed by Orlando et al. [26]) and thus opens the future possibility of high resolution genetic analyses of many cultural heritage objects [21] (Table 1).

\section{What is protein analysis?}

Proteins make up another of the four main categories of biomolecules. Proteins are composed of chains of molecules called amino acids of which there are 20 different types that naturally occur in the body. The sequence of these specific amino acids is what gives proteins their primary structure, and the way this long chain folds up on itself (helices, sheets, etc) confers the proteins secondary and tertiary structure [22]. Proteins are the main functional building blocks of life. They have very varied functions including structural (collagen), enzymatic (trypsin), transport/storage (haemoglobin), immunological (antibodies) and messenger functions (hormones). Proteins seem to have much more robust survival rates than DNA, with some of the earliest proteins identified dated to over 3.8 million years [27]. By looking at the profile (or fingerprint) of one particular protein using mass spectrometry we can identify the species of animal it came from. This basic form of protein analysis is called peptide mass fingerprinting (PMF) and is the basis for the ZooMS [28] technique later adapted into eZooMS [3] for noninvasive use on parchment. The study of all the proteins present in a sample is known as proteomics and when applied to historic or ancient proteins it is called palaeoproteomics [29-31]. Much like DNA, minor changes in the sequence of proteins (primary structure) can allow us to discriminate between different species, allowing species identification [32, 33].

A major advantage of proteomic based studies is that proteins have tissue specificity; while the DNA of every cell is identical, proteins are specific to different tissues and environments, allowing the identification of not only the species but also of the biological tissue [34, 35]. For example it would be possible to detect the proteins present in egg white glares on the surfaces of some parchments thus allowing for a species ID (chicken), as would DNA, but also confirming proteomically that the substance is egg white, which would not be possible through DNA analysis.

\section{What is the microbiome?}

Over the last decade there has been a dramatic shift in the way we think about the microorganisms surrounding us [36]. Since the launch of the Human Microbiome Project in 2007 microbes have taken centre stage in the study of health and disease, highlighting how dependant we are on these microscopic organisms in all aspects of our daily lives [37]. Microbiomes (the community of microorganisms in a certain ecological niche) are present not only on humans but in the environment around us, with characteristic communities forming in different locations. Parchment documents also have their own microbiome characteristic to them, formed from its production, history, use and conservation $[4,17,38]$. We can imagine that the microbiome on the surface of these documents as a type of microbial fingerprint or signature, that can provide us with additional information about the history of the object, although interpreting this information is still at an early stage $[4,38]$.

\section{Table 1 Glossary of useful terminology}

\begin{tabular}{|c|c|}
\hline Glossary: DNA & Glossary: Proteins \\
\hline $\begin{array}{l}\text { aDNA: ancient DNA, DNA extracted from ancient specimens. Due to } \\
\text { degradation processes aDNA is of lower quality than modern genetic } \\
\text { material }\end{array}$ & Amino acid: building blocks of proteins, there are 20 different types \\
\hline $\begin{array}{l}\text { Genomics: the branch of molecular biology concerned with the structure, } \\
\text { function, evolution, and mapping of genomes }\end{array}$ & $\begin{array}{l}\text { Enzyme: protein molecules in cells which work as catalysts, speeding up } \\
\text { chemical reactions in the body }\end{array}$ \\
\hline $\begin{array}{l}\text { Metagenomics: study of genetic material recovered directly from environ- } \\
\text { mental samples }\end{array}$ & $\begin{array}{l}\text { LC-MSMS: Liquid chromatography mass spectrometry, frequently used in } \\
\text { proteomics }\end{array}$ \\
\hline $\begin{array}{l}\text { Microbiome: the combined genetic material of the microorganisms in a } \\
\text { particular environment (including the body or a part of the body) }\end{array}$ & $\begin{array}{l}\text { MALDI-TOF MS: matrix assisted laser desorption/ionization-time of flight } \\
\text { mass spectrometry, frequently used for PMF }\end{array}$ \\
\hline mtDNA: mitochondrial DNA, only inherited by the female line & Peptide: short chains of amino acid monomers linked by peptide bonds \\
\hline $\begin{array}{l}\text { NGS: next generation sequencing, also known as high-throughput } \\
\text { sequencing are technologies that allow for sequencing of DNA much } \\
\text { more quickly and cheaply than the previous methods }\end{array}$ & $\begin{array}{l}\text { PMF: peptide mass fingerprinting, a method of protein identification based } \\
\text { on a mass spectrum of a mixture of peptides that come from a digested } \\
\text { protein }\end{array}$ \\
\hline $\begin{array}{l}\text { SNP: single nucleotide polymorphism, a substitution of a single nucleo- } \\
\text { tide that occurs at a specific position in the genome }\end{array}$ & $\begin{array}{l}\text { Proteomics: branch of molecular biology concerned with the large-scale } \\
\text { study of proteins and their functions }\end{array}$ \\
\hline
\end{tabular}




\section{Biocodicology-a step by step guide}

When contemplating a biocodicological analysis of a manuscript there are various aspects that can be investigated: protein analysis, genetic analysis, and visual analysis including animal dimensions, scraping and production marks and evidence of animal disease (Fig. 1).

The selection of the techniques to be employed will depend greatly on the question being posed. In all situations, it is highly recommended to start with the least invasive and costly technique and only move on to other techniques if the question is not answered, in line with ethical sampling guidance provided by The Institute of Conservation (ICON) [39]. Visual analysis should always be the first step in the process, and may in some cases be sufficient. If visual analysis is not enough, our proposed next step would be a minimal non-invasive sampling using PVC erasers to provide samples for a basic form of protein analysis called peptide mass fingerprinting (PMF) [3]. This would provide a species identification and parchment quality index. There is also the possibility of performing a more in-depth proteomic analysis to identify additional proteins from the surface of the document. For more complex questions, if a larger amount of eraser rubbings can be obtained, then DNA analysis can be used to provide information on species, sex, relatedness and microbial presence [4].

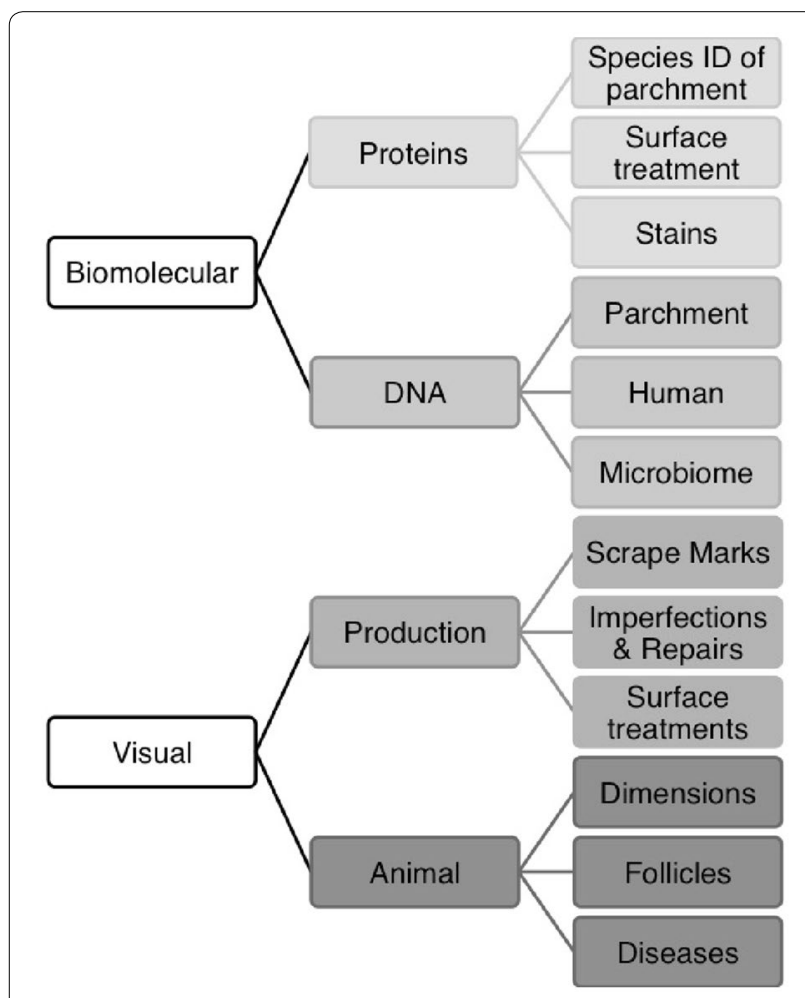

Fig. 1 Methods of biocodicological analysis

\section{Visual analysis \\ Methods of production}

Visual analysis of parchment can be divided into two main categories:

1. The observation of traces left from the manufacture of parchment. This starts with the method of skinning the animal where flay cuts left by the butcher's knife might later open up and create holes during the stretching of the skin on the frame. Some of them are sewn (by various types of stitches), some holes are left or later covered by patches. Many other traces come from the shaving or final treatment of the surface of parchment, including striation marks left by the parchment maker's knife. In most cases the surface treatment completely removes follicle patterns, therefore other criteria must be used to identify the type of skin employed such as its stiffness or flexibility or the curvature of the margin of parchment folios when opened (as a reaction to the climate). Parchment thickness is also an important measure that should be registered [40, 41].

2. The observation and measurement of the anatomical features of the animal visible in the parchment can help to identify the part of the body (e.g. pelvis bone or specific vertebrae) and give us an approximate estimate of size and age. Observation of the position of the spine and the belly of the animal can also help to understand how the skin was divided into sheets (bifolia), which were later organised into the gatherings (quires) of the codex. Identifying the hair and flesh sides is also crucial as it relates to different historical methods of quire construction (including pricking and lining of the folios) and can lead to a better understanding of manuscript production practices in different scriptoria. To help aid these visual identifications it is recommended to observe parchment folios in different types of lighting for example transmitted or raking light $[42,43]$.

\section{Methods of construction}

While parchment documents in archives take the form of flat, rolled or folded deeds, most documents from medieval libraries take the form of a codex. This means that the parchment leaves were secured together to form a three-dimensional object: the book in its binding. The parchment leaves were folded to form bifolios; then 3 , 4, 5 or more bifolios were gathered to make quires. The quires were sewn together as a text block on cords or skin thongs. The construct was strengthened and its opening-how it opens-controlled by the use of various elements depending on the period: this could include tabs, 
endbands and a spine lining. It was then protected by wooden boards and a skin covering. In the Middle Ages, all materials used to make the bindings were carefully selected for their mechanical properties, depending on the role they had to play [44]. Other than the wood used for the boards, the plant fibres used for the sewing thread or fabric linings and, occasionally, metal clasps, all materials were animal based: alum-tawed skin, tanned leather, parchment, fur, silk linings, fish glue, casein glue, egg white finish, beeswax and even tendons to make thread. We study the construction of a book by looking at each of the elements of the binding: how they are put together, but also the materials that were selected for each of these elements [45]. By identifying and examining the various type of skins used to make the structure, we can learn about how the book functioned. It can also tell us what was involved in the manufacture of the book, such as where they were produced, the network of skills involved and even about local production methods and facilities and how the materials were traded.

\section{Evidence of disease}

Finally, a visual inspection of parchment documents can also inform us on the health of the animals used for their production. A variety of diseases and parasites are likely to cause lesions on animal skins, leaving scars that may be recorded in the parchment. The shape, size, nature and anatomical location of these scars, when combined with an identification of the affected species, can in some cases allow the diagnosis of their origin, as different pathogens manifest in different ways on the skin. For instance, warble-fly (Hypoderma bovis) breathing holes and exit holes have long since been identified in the parchment record, as the lesions they produce are unmistakable: small, circular perforations grouped along the line of the back in cattle skins. Other diseases that have not yet been investigated in parchment documents can be identified in a similar way, with ongoing work looking to identify two major medieval sheep conditions, scab and sheep-pox.

\section{Biomolecular analysis}

The most significant advance in the biomolecular analysis of manuscripts has been the development of novel sampling techniques. Manuscripts are highly valued but the great importance attributed to these documents means that analysing them is highly restricted and any form of destructive analysis is highly scrutinised. This means that until now analyses have seen the predominance of noninvasive imaging techniques for example multispectral imaging, XRF and Raman spectroscopy. Although these techniques can provide valuable information, they are insufficient to address more biological questions (regarding species, sex, breed and origin of animals used) that can only be answered through DNA or protein analysis. The development of our non-invasive sampling technique [3] has allowed us access to thousands of previously unanalysed documents all with the approval of conservators and curators.

Our sampling method is based on triboelectric extraction using conventional PVC erasers found in conservation studios. The documents can be sampled in situ, with the eraser crumbs collected and sent to a lab for subsequent analysis without need for specialist conditions or equipment. Depending on the biocodicological analysis that is required different amounts of eraser crumbs will need to be collected (Fig. 2). This process is now accepted by the majority of conservation studios as a non-invasive surface cleaning technique appropriate for parchment documents. Ultimately, the decision of where and whether to sample lies with the conservator who has the best understanding of the condition of the document and might decide in particular cases that a document is too fragile or brittle to be cleaned or sampled in this manner.

When embarking for the first time on a biocodicological analysis we have to start with the question that is being asked because depending on the enquiry a different methodological route should be undertaken. This is best illustrated with some opinionated practical examples, informed by our biocodicological research:

\section{Q. What species of animal is this particular document made from?}

A. For simple species identification the best course of action is to undertake basic protein analysis (eZooMS). This method is cheap, fast and for parchment has a very high success rate (>90\%). Only a tiny amount of eraser crumbs is needed (20 $\mu \mathrm{l}$, Fig. 2a) and only one sample per bifolio. In addition to the species ID we are also able to provide some detail of the production quality of the parchment through the PQI (Parchment Quality Index).

\section{Q. Are these two fragments related?}

A. Initially, eZooMS would be the best first step just to confirm that the two fragments are the same animal and have a similar PQI. The next logical step would be to undergo DNA analysis. This would require a greater amount of eraser crumbs (200 $\mu \mathrm{l}$, Fig. 2b) and therefore the condition of the parchment would need to be assessed. By analysing the mitochondrial data obtained from the animal it would be possible to determine if the fragments belonged to the same maternal line/herd. By doing more in-depth sequenc- 
ing it might be possible to determine if they belong to the same individual. Unfortunately, this comes at a price. DNA analysis is not only more labour and time intensive but it is also much more expensive than protein analysis (Fig. 3). Given the complexity and cost of this type of analysis currently it cannot be carried out routinely and therefore it would be in the interest of all parties (curators, conservators and scientists) to see if the question could be at least partially resolved through other means (previous documentary evidence, palaeography, etc). However, the information that can be obtained through this kind of analysis is a valuable resource for the document, giving us the species, sex, and possibly even how the animals relate to modern breeds in addition to microbial data and evidence of human handling $[4,7$, 23]. This information is crucial in order to gain better insight into how livestock has changed over time, how this may have impacted the economy as a whole, estimates into flock and herd sizes and the kill off patterns used depending on the agrarian economy.

\section{Q. What is this stain?}

A. The best way to approach this question is to undertake proteomic analysis. This is a step further than eZooMS, but doesn't require much more sample, approximately $50 \mu \mathrm{l}$ in volume (Fig. 2c). By undertaking a complete proteomic analysis we can not only determine the species of the parchment and the PQI, but we can also identify all the additional proteins present on the surface of the parchment. Proteomics offers a tissue specificity that DNA cannot provide. The analysis will not only tell you that chicken proteins are present (as would DNA), but they can tell you that those proteins are specific to egg yolk for example. This tissue specificity is much more revealing in the case of stains and gives vital clues as to how the document may have been used in the past. This, of course, does come at a cost as it is more expensive than basic eZooMS and takes longer, but it is significantly cheaper and quicker than DNA analysis and more informative in the case of stains.

\section{Q. I am concerned about the condition of a document, could there be potentially damaging bacteria or fungi present?}

A. Here the answer lies in the analysis of the microbiome. By using eraser crumbs we are preferentially removing surface DNA, which comprise the bacteria

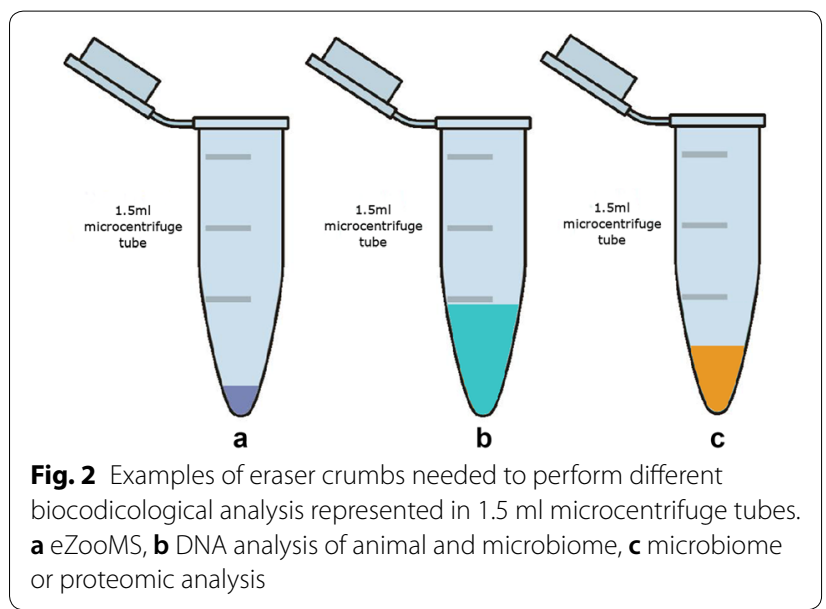

and fungi that have or are still inhabiting the surface of the document, therefore the amount of sequencing (data) required in order to get an informative answer is likely to be less than for animal genetic analyses. However, although species can be detected we still don't know how likely they are to be directly implicated in damaging the object, so further studies and analysis will need to be carried out before definitive links can be established. Although, pioneering studies are starting to emerge in this area $[18,38,46]$.

Finally amongst all these other decisions we must also take into account the original substrate as not all materials have the same biomolecular profile and it might be difficult to obtain specific results for certain materials (outlined in Table 2). We know that obtaining host DNA from tanned skins is often not possible (as the tanning process adversely affects the host nuclear DNA although some mitochondrial DNA may survive $[47,48]$ ) so this should be taken into consideration when designing your biocodicological strategy.

\section{Conclusions}

The recent biomolecular revolution is changing the way we think about archaeological and historic artefacts and challenging our views on what information can be garnered from these heritage objects. Until recently the majority of biomolecular techniques required some form of destructive sampling, albeit very small amounts, but although destructive sampling is widely accepted in the archaeological community (in part due to the long-standing use of radiocarbon dating techniques) it contravenes most conventions for manuscript curation and conservation. This has meant that only a select few documents have been subjected to this kind of analysis with little interest in the widespread adoption of these techniques. 


\section{Average time per sample: $24-48 \mathrm{~h}$ \\ Average price per sample: $\mathbf{£ 5 0}$ \\ Average number of samples processed in one batch: 36}

Trypsin digest

4 hour incubation at $37^{\circ} \mathrm{C}$

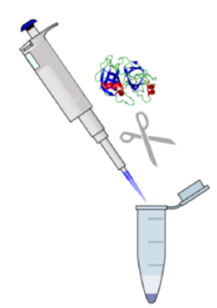

C18 tip cleanup

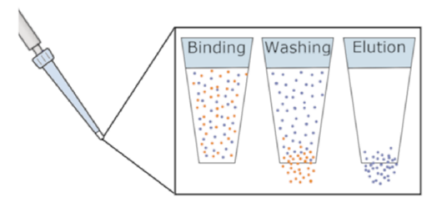

MALDI-TOF

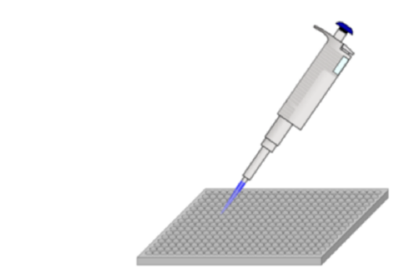

Species ID

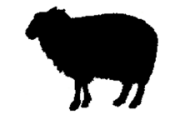

Parchment Quality Index $37^{\circ} \mathrm{C}$
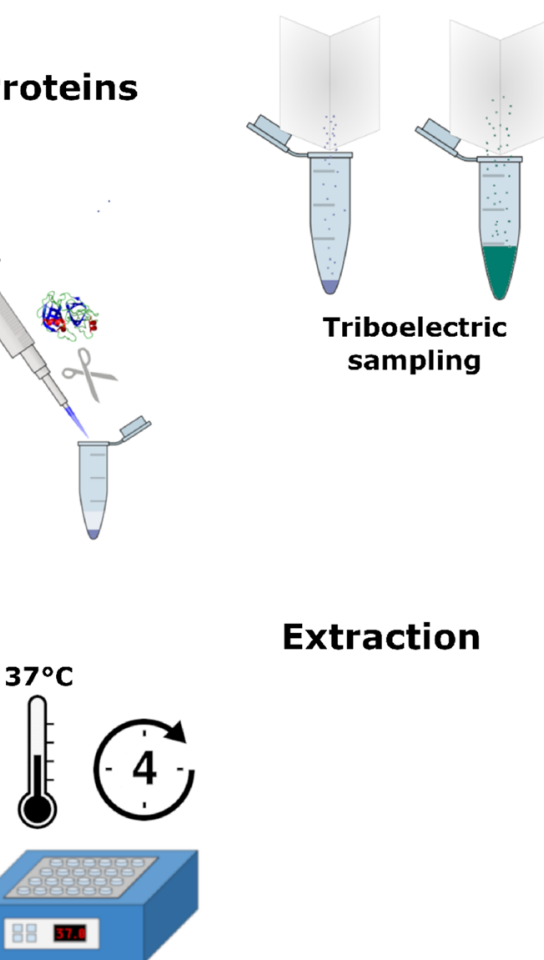

Extraction

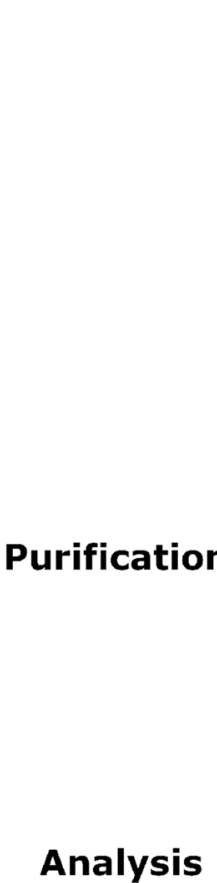

Analysis

Results

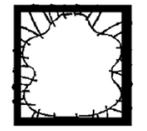

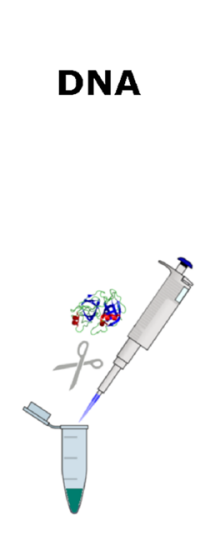

Average time per sample: 3-6 mnths

Average price per

sample: $£ 500$

Average number of samples processed

in one batch: 12

Enzyme digest

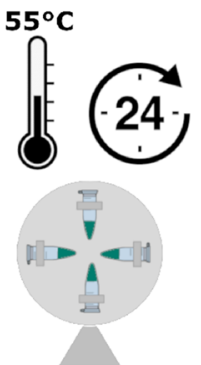

24 hour incubation at $55^{\circ} \mathrm{C}$

Silica column cleanup

A T A G A A T T GA GCTGG GCTTC $C G C A C T G A A T$ T C G A A T C G G C $C A A G C C G G A T$

aDNA library building and NGS

$$
\underline{+}
$$

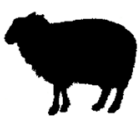

Species ID

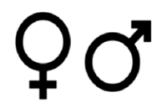

Sex

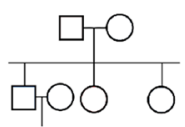

Fig. 3 Overview of proteomic and genetic methods applied in biocodicology 
Table 2 Summary of information that can be obtained from different substrates

\begin{tabular}{|c|c|c|c|c|c|c|}
\hline Sample type & Animal ID (eZooMS) & PQI & Animal ID (DNA) & Sex of animal & Microbiome & $\begin{array}{l}\text { User } \\
\text { DNA } \\
\text { (human) }\end{array}$ \\
\hline Parchment & $\checkmark$ & $\checkmark$ & $\checkmark$ & $\checkmark$ & $\checkmark$ & $\checkmark$ \\
\hline Tanned leather & $\checkmark$ & $\checkmark$ & $?$ & $?$ & $\checkmark$ & $\checkmark$ \\
\hline Alum tawed skin & $\checkmark$ & $\checkmark$ & $?$ & $?$ & $\checkmark$ & $\checkmark$ \\
\hline Paper & - & - & - & - & $\checkmark$ & $\checkmark$ \\
\hline
\end{tabular}

The price of biomolecular analysis has also been a limiting factor. Many archives and libraries have extremely limited funds with which to both conserve and archive documents and find that any form of analysis is out of their reach. Although the prices for DNA sequencing have dropped dramatically in the past decade, this analysis can easily run into hundreds if not thousands of pounds, an important factor to take into consideration when working with the limited funds available to libraries and archives.

We are now in a position to be able to address both these issues. Our development of a non-invasive sampling technique has been fundamental to this step change in how we approach biocodicology. By using a technique that was developed alongside conservators and that is widely accepted in the conservation community we have been able to broaden our access to documents from just a handful to thousands. As our triboelectric sampling technique is used in situ by the conservators themselves we remove the logistical problems of transporting precious documents. All sampling can be done in house by a conservator with no need for specialist equipment or training. An additional advantage to using our triboelectric extraction when compared to destructively taken physical samples, is that we are preferentially extracting the surface biomolecules (including surface treatment and stains, as well as the microbiome) and not overwhelming the extraction with the underlying collagen and animal DNA.

The cost of analysing these samples is decreasing year on year and is becoming much more plausible to fund. However, research funding for libraries and archives is still quite limited and usually not substantial enough to routinely include these types of analyses. However, by highlighting the biobank contained within parchment we hope to encourage increased funding in this area, this will not only benefit the conservation of the document but could also help to sustainably unlock the vital biological record it contains.

As with any other emerging field, there are numerous groups working on similar problems using different methods to tackle the same questions. Numerous groups have successfully analysed host DNA as well as the microbiome of various historical documents using NGS $[7,38,46]$. There has also been differing non-invasive methods developed to recover proteins from both paper and parchment documents [49-51] revealing evidence of disease and substance use, which can open exciting new avenues of research.

One question that must be addressed is that of dating. This is one of the most frequent requests that researchers have and are eager to resolve. Documents can be dated through direct textual evidence (if a date of production is present) but more often these objects are dated on paleographical details, that although are incredibly helpful are not without problems and often can only offer a date range rather than a precise date. Radiocarbon dating does provide a more precise form of dating, however this comes at a cost and is also generally reported as a calibrated date range. It necessarily requires destructive sampling of at least 3-10 mg [52] which, as we have previously discussed, is not routinely accepted by most conservators and curators and can therefore only be used when the object is considered of such high importance that the potential results merits the destructive samples [53-56]. We would also advocate that any sample remaining from a radiocarbon analysis be identified as the important biobank that it is and hopefully not discarded but used for other analyses. Finding an objective method of dating that does not require destructive analysis is a prime objective. Our current techniques explained above, unfortunately, cannot yet provide this; at best, we could possibly use the genetic data to provide a form of relative dating (e.g. document $\mathrm{X}$ is older than document $Y)$ which does not solve the issue of precise dating. As sensitivity increases and new methods appear, there may emerge a possibility for objective discreet dating of parchments using non-invasive procedures and this in turn would prove to be another revolution in what we know about historical manuscripts.

Biocodicology offers the possibility of interrogating manuscripts in a novel and informative way. The generation of biological data associated to parchment documents will add a further level of understanding and interpretation to these invaluable objects. As methods continue to improve we hope that biocodicology will 
become a highly relevant discipline in manuscript studies, contributing a different but complementary perspective to the current scholarship. We hope this somewhat opinionated review will act as a catalyst to further interactions between the heritage science community and parchment scholars, curators and conservators.

\section{Abbreviations}

NGS: next generation sequencing; HTS: high throughput DNA sequencing techniques; PMF: peptide mass fingerprinting; eZooMS: electrostatic Zooarchaeology by Mass Spectrometry; PQI: Parchment Quality Index.

\section{Acknowledgements}

The authors would like to thank all archives, libraries and institutions, who have facilitated our biocodicological studies without whom this work would not be possible.

\section{Authors' contributions}

SF, MDT and MJC developed the concept of this work, SF and MDT wrote the paper with revisions, contributions and comments and from all other authors. All authors read and approved the final manuscript.

\section{Funding}

This work was supported by ERC investigator Grants 787282-B2C and 295729-CodeX. SF was additionally supported by the Marie Curie International Fellowship PALIMPSEST FP7-PEOPLE-2011-IEF 299101 and British Academy Postdoctoral Fellowship funding, MDT received funding from the European Union's Horizon 2020 research and innovation programme under the Marie Sklodowska-Curie Grant agreement No. 747424 (SCRIBE). MJC is also supported by the Danish National Research Foundation-DNRF128.

\section{Availability of data and materials}

Not applicable.

\section{Competing interests}

The authors declare that they have no competing interests.

\section{Author details}

${ }^{1}$ BioArCh, Department of Archaeology, University of York, York YO10 5DD, UK. ${ }^{2}$ Department of Preservation, The Royal Library, 1016 Copenhagen K, Denmark. ${ }^{3}$ Department of History, University of York, York YO10 5DD, UK. ${ }^{4}$ ArScAn, Université Paris X Nanterre-La Défense, Université Paris Nanterre, 92001 Nanterre, France. ${ }^{5}$ Department of Preservation, Trinity College Library, Trinity College Dublin, Dublin 2, Ireland. ${ }^{6}$ Department of Archaeology, University of Paris 1 Panthéon-Sorbonne, 3 rue Michelet, 75006 Paris, France. ${ }^{7}$ Department of Archaeology, University of Cambridge, Cambridge CB2 3DZ, UK. ${ }^{8}$ Museum of Natural History, University of Copenhagen, Copenhagen, Denmark.

Received: 5 March 2019 Revised: 20 May 2019 Accepted: 25 May 2019 Published online: 07 June 2019

\section{References}

1. Bower MA, Campana MG, Checkley Scott C, Knight B, Howe CJ. The potential for extraction and exploitation of DNA from parchment: a review of the opportunities and hurdles. J Am Inst Conserv. 2010;33:1-11.

2. Turner NK. The materiality of medieval parchment: a response to "The Animal Turn". Rev Hisp Mod. 2018;71:39-67.

3. Fiddyment S, Holsinger B, Ruzzier C, Devine A, Binois A, Albarella U, et al. Animal origin of 13th-century uterine vellum revealed using noninvasive peptide fingerprinting. Proc Natl Acad Sci USA. 2015;112:15066-71.

4. Teasdale MD, Fiddyment S, Vnouček J, Mattiangeli V, Speller C, Binois A, et al. The York Gospels: a 1000-year biological palimpsest. R Soc Open Sci. 2017:4:170988.
5. Wight C. Glossary for the British Library catalogue of illuminated manuscripts. The British Library. https://www.bl.uk/catalogues/illuminate dmanuscripts/GlossC\%2Easp. Accessed 1 Mar 2019

6. CODICOLOGIE. Définition de CODICOLOGIE. https://www.cnrtl.fr/lexic ographie/codicologie. Accessed 1 Mar 2019.

7. Shepherd LD, Whitehead P, Whitehead A. Genetic analysis identifies the missing parchment of New Zealand's founding document, the Treaty of Waitangi. PLoS ONE. 2019;14:e0210528.

8. Ryder ML. Follicle arrangement in skin from wild sheep, primitive domestic sheep and in parchment. Nature. 1958;182:781-3.

9. Ryder ML. Follicle remains in some British parchments. Nature. 1960;187:130-2.

10. Stinson T. Counting sheep: potential applications of DNA analysis to the study of medieval parchment production. In: Franz F, Fritze C, Vogeler G, editors. Kodikologie und Paläographie im digitalen Zeitalter 2-Codicology and Palaeography in the Digital Age 2. Norderstedt: Books on Demand (BoD); 2011. p. 191-207.

11. Stinson TL. Knowledge of the flesh: using DNA analysis to unlock bibliographical secrets of medieval parchment. Pap Bibliogr Soc Am. 2009:103:435-53.

12. Woodward SR, Kahila G, Smith P, Greenblatt C, Zias J, Broshi M. Analysis of parchment fragments from the Judean Desert using DNA techniques. In: Parry DW, Ricks S, editors. Current research and technological developments on the Dead Sea Scrolls. Leiden: Brill; 1996. p. 215-38.

13. Burger J, Hummel S, Herrmann B. Palaeogenetics and cultural heritage. Species determination and STR-genotyping from ancient DNA in art and artefacts. Thermochim Acta. 2000;365:141-6.

14. Poulakakis N, Tselikas A, Bitsakis I, Mylonas M, Lymberakis P. Ancient DNA and the genetic signature of ancient Greek manuscripts. J Archaeol Sci. 2007:34:675-80.

15. Campana MG, Bower MA, Bailey MJ, Stock F, O'Connell TC, Edwards CJ, et al. A flock of sheep, goats and cattle: ancient DNA analysis reveals complexities of historical parchment manufacture. J Archaeol Sci. 2010:37:1317-25.

16. Toniolo L, D'Amato A, Saccenti R, Gulotta D, Righetti PG. The Silk Road, Marco Polo, a Bible and its proteome: a detective story. J Proteomics. 2012;75:3365-73

17. Pinzari F, Troiano F, Piñar G, Sterflinger K, Montanari M. The contribution of microbiological research in the field of book, paper and parchment conservation. In: Engel P, editor. New approaches to book and paper conservation-restoration. Horn: Verlag Berger; 2011. p. 575-594.

18. Piñar G, Sterflinger K, Pinzari F. Unmasking the measles-like parchment discoloration: molecular and microanalytical approach. Environ Microbiol. 2015;17:427-43

19. Piñar G, Tafer H, Sterflinger K, Pinzari F. Amid the possible causes of a very famous foxing: molecular and microscopic insight into Leonardo da Vinci's self-portrait. Environ Microbiol Rep. 2015. https://doi. org/10.1111/1758-2229.12313.

20. Lech T. Evaluation of microbial hazard of parchment documents on an example of the 13th century Incorporation Charter for the city of Krakow. Appl Environ Microbiol. 2016;82:2620-31.

21. Bi K, Linderoth T, Vanderpool D, Good JM, Nielsen R, Moritz C. Unlocking the vault: next-generation museum population genomics. Mol Ecol. 2013. https://doi.org/10.1111/mec.12516.

22. Stryer L, Tymoczko J, Gatto G. Biochemistry. 9th ed. New York: WH Freeman; 2019.

23. Teasdale MD, van Doorn NL, Fiddyment S, Webb CC, O'Connor T, Hofreiter $M$, et al. Paging through history: parchment as a reservoir of ancient DNA for next generation sequencing. Philos Trans R Soc Lond B Biol Sci. 2015;370:20130379.

24. Lech T. A discovered ducal seal does not belong to the incorporation charter for the city of Krakow solving the mystery using genetic methods. PLoS ONE. 2016;11:e0161591.

25. Lech T. Ancient DNA in historical parchments-identifying a procedure for extraction and amplification of genetic material. Genet Mol Res. 2016;15:gmr8661.

26. Orlando L, Gilbert MTP, Willerslev E. Reconstructing ancient genomes and epigenomes. Nat Rev Genet. 2015;16:395-408. 
27. Demarchi B, Hall S, Roncal-Herrero T, Freeman CL, Woolley J, Crisp MK et al. Protein sequences bound to mineral surfaces persist into deep time. Elife. 2016;5:e17092. https://doi.org/10.7554/eLife.17092.

28. Buckley M, Fraser S, Herman J, Melton N, Mulville J, Pálsdóttir A. Species identification of archaeological marine mammals using collagen fingerprinting. J Archaeol Sci. 2014;41:631-41.

29. Cleland TP, Schroeter ER. A comparison of common mass spectrometry approaches for paleoproteomics. J Proteome Res. 2018. https://doi. org/10.1021/acs.jproteome.7b00703.

30. Hendy J, Welker F, Demarchi B, Speller C, Warinner C, Collins MJ. A guide to ancient protein studies. Nat Ecol Evol. 2018. https://doi.org/10.1038/ s41559-018-0510-X

31. Welker F. Palaeoproteomics for human evolution studies. Quat Sci Rev. 2018;190:137-47.

32. Brown S, Higham T, Slon V, Pääbo S, Meyer M, Douka K, et al. Identification of a new hominin bone from Denisova Cave, Siberia using collagen fingerprinting and mitochondrial DNA analysis. Sci Rep. 2016;6:23559.

33. Welker F, Collins MJ, Thomas JA, Wadsley M, Brace S, Cappellini E, et al. Ancient proteins resolve the evolutionary history of Darwin's South American ungulates. Nature. 2015. https://doi.org/10.1038/nature14249.

34. Hendy J, Colonese AC, Franz I, Fernandes R, Fischer R, Orton D, et al. Ancient proteins from ceramic vessels at Çatalhöyük West reveal the hidden cuisine of early farmers. Nat Commun. 2018;9:4064.

35. Warinner C, Hendy J, Speller C, Cappellini E, Fischer R, Trachsel C, et al. Direct evidence of milk consumption from ancient human dental calculus. Sci Rep. 2014;4:7104

36. Blaser MJ. The microbiome revolution. J Clin Invest. 2014;124:4162-5.

37. Human Microbiome Project Consortium. Structure, function and diversity of the healthy human microbiome. Nature. 2012:486:207-14.

38. Migliore L, Perini N, Mercuri F, Orlanducci S, Rubechini A, Thaller MC. Three ancient documents solve the jigsaw of the parchment purple spot deterioration and validate the microbial succession model. Sci Rep. 2019;9:1623.

39. Quye A, Strlič M. Ethical Sampling Guidance-lcon Heritage Science Group. The Institute of Conservation (ICON); 2019. https://icon.org.uk/ groups/heritage-science/guidance-documents

40. Vnouček J. The manufacture of parchment for writing purposes and the observation of the signs of manufacture surviving in old manuscripts. In: Proceedings of the eighth international seminar held at the University of Copenhagen 16th-17th October 2003. 2005. p. 74-92.

41. Vnouček J. Production of parchment for a handmade replica of the treaty of Kiel from 1814. In: Johansen K, Petersen ML, editors. Making a Replica of the Treaty of Kiel. Oslo: The Royal library, The Norwegian Parliament Archives; 2015.

42. Vnouček J. Illustrations for instruction, the book as evidence: the story of the production of a medieval codex as recorder in the Hamburg Bible. In: From Nature To Script. Snorrastofa, cultural and medieval centre; 2012. p. $199-229$.
43. Vnouček J, Fiddyment S. On the parchment of the Privilegium maius charters. I: Falsche Tatsachen. In: Griesser M, Just T, Kininger K, Kirchweger F, editors. Technologische Studien. Vienna: Kunst Historisches Museum Wien; 2018.

44. Lévêque É. Les Reliures de l'abbaye de Clairvaux: structure et matériaux. La Gazette du livre médiéval. 2017;63:41-54.

45. Lévêque É, Chahine C. Libri pilosi: la peau houssée sur les reliures médiévales. Support/Tracé. 2017;17:63-71.

46. Migliore L, Thaller MC, Vendittozzi G, Mejia AY, Mercuri F, Orlanducci $\mathrm{S}$, et al. Purple spot damage dynamics investigated by an integrated approach on a $1244 \mathrm{AD}$ parchment roll from the Secret Vatican Archive. Sci Rep. 2017;7:9521.

47. Vuissoz A, Worobey M, Odegaard N, Bunce M, Machado CA, Lynnerup N, et al. The survival of PCR-amplifiable DNA in cow leather. J Archaeol Sci. 2007;34:823-9.

48. O'Sullivan NJ, Teasdale MD, Mattiangeli V, Maixner F, Pinhasi R, Bradley DG, et al. A whole mitochondria analysis of the Tyrolean Iceman's leather provides insights into the animal sources of Copper Age clothing. Sci Rep. 2016;6:31279.

49. D'Amato A, Zilberstein G, Zilberstein S, Golovan MI, Zhuravleva AA, Righetti PG. Anton Chekhov and Robert Koch cheek to cheek: a proteomic study. Proteomics. 2018. https://doi.org/10.1002/pmic.201700447.

50. Zilberstein G, Maor U, Baskin E, D’Amato A, Righetti PG. Unearthing Bulgakov's trace proteome from the Master i Margarita manuscript. J Proteom. 2017;152:102-8.

51. D'Amato A, Zilberstein G, Zilberstein S, Compagnoni BL, Righetti PG. Of mice and men: traces of life in the death registries of the 1630 plague in Milano. J Proteom. 2018. https://doi.org/10.1016/j.jprot.2017.11.028.

52. Brock F. Radiocarbon dating of historical parchments. Radiocarbon. 2013;55:353-63.

53. Donahue DJ, Olin JS, Harbottle G. Determination of the radiocarbon age of parchment of the Vinland Map. Radiocarbon. 2002;44:45-52.

54. Bonani G, Ivy S, Wölfli W, Broshi M, Carmi I, Strugnell J. Radiocarbon dating of fourteen Dead Sea Scrolls. Radiocarbon. 1992;34:843-9.

55. Atwill J, Braunheim S, Eisenman R. Redating the radiocarbon dating of the Dead Sea Scrolls. Dead Sea Discov. 2004;11:143-57.

56. Rasmussen KL, van der Plicht J, Doudna G, Nielsen F, Højrup P, Stenby EH, et al. The effects of possible contamination on the radiocarbon dating of the Dead Sea Scrolls II: empirical methods to remove castor oil and suggestions for redating. Radiocarbon. 2009;51:1005-222.

\section{Publisher's Note}

Springer Nature remains neutral with regard to jurisdictional claims in published maps and institutional affiliations.

\section{Submit your manuscript to a SpringerOpen ${ }^{\circ}$ journal and benefit from:}

- Convenient online submission

- Rigorous peer review

- Open access: articles freely available online

- High visibility within the field

- Retaining the copyright to your article

Submit your next manuscript at springeropen.com 